\title{
CHANGES IN DEPTH DISTRIBUTION AND ACTIVITY IN SMALL BENTHIC RIVERINE FISHES UNDER GRADUALLY CHANGING LIGHT INTENSITIES
}

\author{
J. Prenda ${ }^{1}$, S. Rossomanno ${ }^{2}$ and P. D. Armitage ${ }^{3}$ \\ 1. Departamento de Ciencias Agroforestales, Facultad de Ciencias Experimentales, Universidad de Huelva, \\ Campus de La Rábida, 21819 Palos de la Frontera, Huelva, Spain. E-mail: jprenda@uhu.es. 2. Quercianella, via \\ dei Ginepri 25, 57015 Livorno, Italy. 3. Institute of Freshwater Ecology, River Laboratory, East Stoke, \\ Wareham, Dorset BH20 6BB, UK.
}

\begin{abstract}
Three experiments were performed to determine how changes in light conditions affect the activity patterns of three small benthic fishes (Barbatula barbatula, Gobio gobio and Cottus gobio) and if they had any influence on fish microhabitat selection. First, the depth used by three individuals of each species was monitored when light conditions changed at dusk in an aquarium with three depth levels. During daylight most fish stayed in the deep level, but at dusk fish began to move from deeper zones to the shallow one. Second, to test the effect of gradually changing light intensity on bullhead depth use and activity, the aquarium was set up with controlled artificial light in a completely dark room. As light intensity increased, the mean number of fish in the deep level significantly increased and, reciprocally, the mean number of fish in the shallow and medium levels significantly decreased. Third, the variation in bullhead activity under different light intensities was measured by counting the number of pecks and jumps of focal individuals per five minutes. Fish activity diminished as light intensity increased, being highest when light intensity was near zero. Thus, small benthic fish such as bullhead use different microhabitats during the day than at night and display activity peaks during night.
\end{abstract}

Key words: fish microdistribution, microhabitat preferences, stream fish, Cottus gobio, nocturnal activity

\section{RESUMEN}

Se realizaron tres experimentos para determinar cómo los cambios en la intensidad lurninica afectaban a los patrones de actividad de tres especies de pequeños peces bentdnicos (Barbatula barbatula, Gobio gobio y Cottus gobio) y si estos cambios lumínicos tenían algun efecto sobre los patrones de seleccidn de microha'bitats.En primer lugar se observó en un acuario con tres profundidades distintas, el efecto de la luz natural sobre la profundidud seleccionada por tres individuos de cada una de las especies estudiadas, especialmente cuando las condiciones luminicas cambiaban durante la puesta de sol. Durante el dia la mayoría de los peces se localizaba en el nivel más profundo, pero durante la puesta de sol los peces comenzaban a desplazarse hacia el nivel más somero. En segundo lugar, para testifcar el efecto del cambio gradual en la intensidad de la luz sobre la seleccidn de profundidades y los patrones de actividad del cavilat, el acuario se instald en una habitacidn completamente oscura, donde la intensidad luminica podia ser controlada artificialmente. Conforme se incrementaba la intensidad luminica, el número medio de individuos en el nivel más profundo igualmente se incrementaba y, recíprocamente, el número medio de individuos en los niveles somero e intermedio decrecia significativamente. En tercer lugar, se midió la variacidn en la actividad del cavilat bajo diferentes intensidades lurninicas mediante el conteo del número de saltos y picoteos cada cinco minutos de individuos focales. La actividad de los peces disminuyd conforme se incrementó la intensidad luminica, siendo máxima cuando la intensidad luminica estuvo prdxima a cero luxes. De aquí se sugiere que los peces pequeños bentdnicos, tales como el cavilat, usan diferentes microha'bitats durante el díafrente a la noche y muestran picos de actividad durante la noche.

Palabras clave: microdistribución de peces, preferencias de microhábitat, peces fluviales, Cottus gobio, actividad nocturna 


\section{INTRODUCTION}

Light intensity plays a major role in the fish ecology in temperate regions (Diehl, 1988). The daily changes in light intensity have been reported to affect the patterns of fish microhabitat use, mostly when these changes are more pronounced, i.e. at down and dusk. Numerous fish species move inshore at night looking for refugia from predation and/or feeding sites (Copp \& Jurajda, 1993). Shallow banks usually provide more food than deeper areas but present a greater risk from wading predators, whereas deeper waters are used by large piscivorous fishes (Power, 1984; Schlosser, 1988; Eklov et al., 1994).

Previous observations have shown that loach (Barbatula barbatula), bullhead (Cottus gobio) and gudgeon (Gobio gobio) are mostly active in the dark (Smyly, 1955, 1957; Andreasson, 1969; Welton et al., 1983, 1991; Copp \& Jurajda, 1993). However, few works (Andreasson, 1969, 1973) have addressed how the changes in light conditions affect the activity patterns of these species and most importantly if they have any influence on fish microhabitat selection. We test these questions by analysing how fish distributed themselves between three depth levels and how they behaved when light intensity was gradually changed.

\section{MATERIALS AND METHODS}

Fish were captured by electrofishing in the Mill Stream, a side channel from the river Frome (Dorset) (Nat. Grid. Ref. SY 872870). Fish were held for two days in a 1001 stock tank fed with a continuous through-flow of river water. All fish were kept in the tank for approximately two days before they were needed for experiments. Different fish were employed in each experiment.

Two sets of experiments were carried out to test for the role of light intensity on activity patterns and depth use of stone loach, gudgeon and, particularly, bullhead. The experiments were conducted in a 'perspex' aquarium $(100 \mathrm{~cm}$ x 40 $\mathrm{cm} \times 50 \mathrm{~cm}$ ). Water was aerated continuosly. A screened partition separated the aeration area from the experimental arena to avoid disturbance from bubbles. The water temperature was in the range $17-21^{\circ} \mathrm{C}$.

Three depth levels were established in the aquarium at $15 \mathrm{~cm}$ (deep), $10 \mathrm{~cm}$ (medium) and $5 \mathrm{~cm}$ (shallow), respectively. Sand $(<1 \mathrm{~mm})$ was used as substratum. Between 100-120 large live chironomid larvae, mostly last instar Prodiame$s a$ sp., were added to the aquarium, in a similar proportion over the three depth levels, approximately $3 \mathrm{~h}$ before the introduction of the fish, to allow the larvae to distribute homogeneously into the substratum. The aquarium was set up under two different light conditions: natural (i) and artificial (ii).

i) To test if the three species move to shallow depths when light conditions changed at dusk, we monitored the depth used by three bullheads (mean total length $\pm 1 \mathrm{SE}: 60.5 \pm 1.2 \mathrm{~mm}$ ), three gudgeon $(103.2 \pm 5.6 \mathrm{~mm})$ and three stone loach $(65.4 \pm 0.5 \mathrm{~mm})$. Fish were added to the aquarium at 14:00 h. Fish positions were monitored each $15 \mathrm{~min}$. between 18:00 and 22:00 $\mathrm{h}$ in daylight on the 22 June 1994. On each occasion, the number of individuals of each species found per depth was noted. One side of the aquarium received natural light from a north facing window $(0.75 \mathrm{~m} \times 1.25 \mathrm{~m})$ placed back. The remaining three aquarium sides were covered by a large opaque black plastic curtain to prevent fish from being startled when the aquarium was approached. Fish were observed from a small opening in the plastic curtain.

Bullhead were chosen to continue the experiments on the interactions between light, depth and activity. This species was only investigated previously to test the influence of light and activity by Andreasson (1969), but in very different environmental conditions and was easily handled.

ii) To test the effect of gradually changing light intensity on bullhead depth use and activity, the aquarium was set up with controlled artificial light in a completely dark room. The light was supplied by two halogen lamps placed approximately $50 \mathrm{~cm}$ above the aquarium and a red dark 


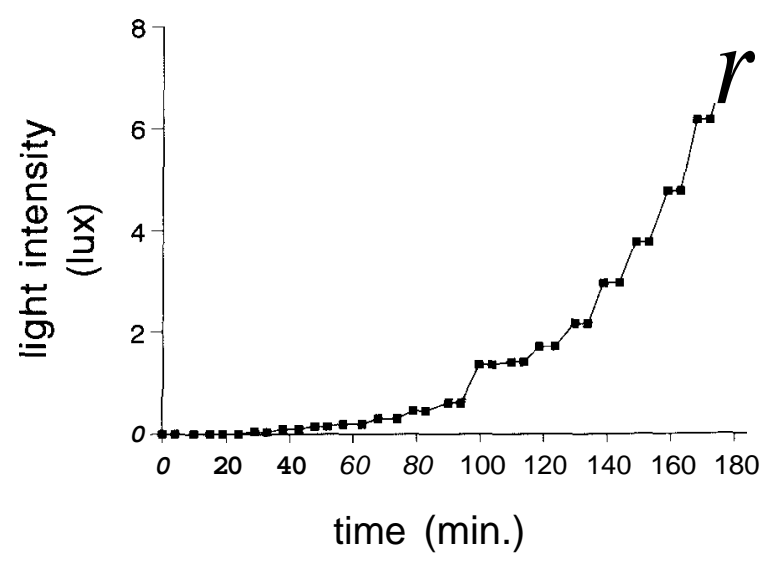

Figure 1. Controlled changes in light intensity (lux) vs. time. Filled squares represent fish depth counts. Cambios controlados en la intensidud de la luz (lux)frente al tiernpo. Los cuadrudos indicun el moneto en el que se reulizaron conteos de peces.

room lamp. This red light, not visible to fish, allowed us to observe fish behaviour when white light intensity was zero. The white lights were diffused with a sheet of translucent white plastic, producing a uniform indirect light. Light intensity was measured using a luximeter, with the sensor placed just besides the aquarium. The light was varied gradually between 0 (red light) and 7.4 lux, approximately following an exponential curve (Fig. 1).

Six bullheads (mean total length \pm SE, $61.2 \pm$ $1.2 \mathrm{~mm}$ ) were added to the aquarium aeration area 4 hours before the experiment, to allow acclimatisation. Once the fish were introduced in the experimental arena the number of individuals per depth were recorded twice per light intensity level (seventeen levels, see Fig. 1), usually at intervals of approximately 1 to 3 minutes, during 3 hours. The exception was the 0 lux level when six observations were made.

iii) To analyse the variation of bullhead activity under different light intensities, we counted the number of pecks and jumps of a focal individual per five minutes. Fish were usually immobile over the substratum. They changed their position by small jumps. Pecking was related to food acquisition and by peclung they seemed to pick

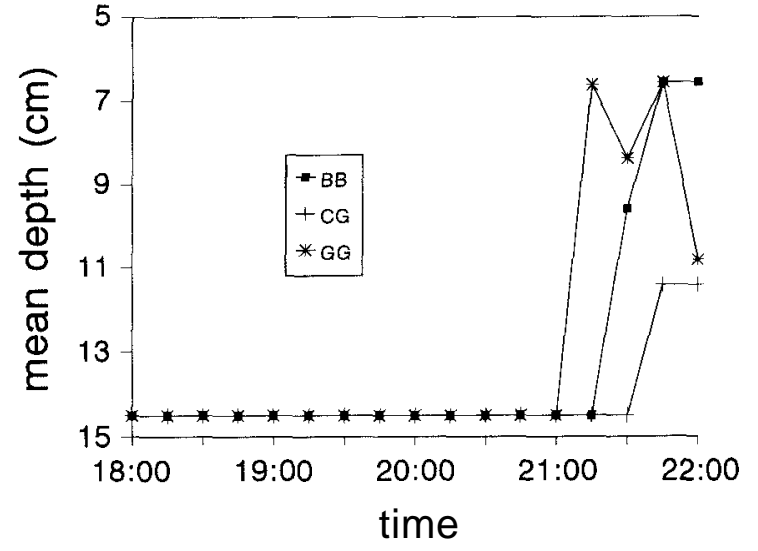

Figure 2. Mean depths selected by bullhead (CG), stone loach (BB) and gudgeon (GG) between 18:00 and 22:00. Dusk began after 21:00 h. Profundidades medias seleccionudus por el cavilat ( $C G)$, el lobo de río (BB) y el gobio $(G G)$ entre las 18:00 y las 22:00. La puesta de sol comenzd a las 21:00.

up small particles from the substratum. These observations were carried out simultaneously as the previous experiment (ii). A total of 59 recordings of focal individuals was made during a mean interval $( \pm \mathrm{SE})$ of $3.1 \pm 0.05$ min., with observations distributed as evenly as possible between depth levels.

\section{RESULTS}

\section{Experiment 1}

Most fish stayed inactive in the deep level during daylight. Fish began to move from deeper zones to the shallow one at dusk (Fig. 2). This change in depth level was very sharp and seemed to follow a species sequence. Gudgeon was the first to move out, followed by stone loach and bullhead, respectively.

\section{Experiment 2}

The light level had a clear influence on depth selection by bullhead. Some bullheads changed their position in response to changes in light intensity and some stayed in the deep level. Only 
Table 1. Summary of linear and non-linear regression between the light intensity (independent variable) and the mean number of bullhead per each one of the three depth levels studied (dependent variable). $n=17$. Resumen de las regresiones lineares y no lineares entre la intensidad de la luz (variable independiente) y el número rnedio de cavilats por cada uno de las tres profundidades consideradas (variable dependiente). $n=17$.

\begin{tabular}{lccccccc}
\multirow{2}{*}{ depth level } & \multicolumn{3}{c}{ linear } & & & & non linear \\
\cline { 2 - 3 } \cline { 7 - 7 } & $\mathbf{F}$ & $\mathbf{P}$ & $\mathbf{R}^{\mathbf{2}}(\boldsymbol{\%})$ & & ratio & $\mathbf{R}^{\mathbf{2}}(\boldsymbol{\%})$ \\
\hline shallow & 4.8 & 0.045 & 24.1 & & 133.7 & 32.0 \\
medium & 6.0 & 0.027 & 28.7 & & 184.3 & 23.9 \\
deep & 14.5 & 0.0017 & 49.1 & & 1618.5 & 80.0 \\
\hline
\end{tabular}

a few used the shallow one (usually less than one as average per light intensity level) (Fig. 3). In general, as light intensity increased, the mean number of fish in the deep level significantly increased and at the same time, the mean number of fish in the shallow and medium levels significantly decreased (Fig. 3). The linear regression lines between the light vs. the mean number of fish per depth level were all significant $(\mathrm{P}<0.046)$, although the best regressions in two cases were non-linear. The exception was the medium level for which a reciprocal model provided the best fit (Table 1).

\section{Experiment 3}

Light level not only affected to depth selection of bullheads but also their activity. This activity measured as jumps and pecks per second, respectively, diminished as light intensity increased (Table 2, Fig. 4). When light intensity was near zero, fish activity was greatest. At higher values of light intensity fish became less active (Fig. 4). However, there were many inter-individual differences in activity that affected jumping. With respect to 'jump' activity, fish that remained in the deep level were significantly less active than those in the shallow one (jumps $\mathrm{s}^{-1}$ : multiple range Tukey test, $\mathrm{P}<0.05$; one way ANOVA, $\left.\mathrm{F}_{85}=5.13, \mathrm{P}=0.008\right)$. In contrast, pecks s ${ }^{-1} \mathrm{did}$ not vary between depth levels (one way ANOVA, $P>0.05$ ). In general, all fishes picked up for food but only a minority was both active and used the shallow level. Our efforts to distribute the observations evenly between the three depth, may have masked the different response to varying light intensity of fish in distinct depth levels.

\section{DISCUSSION}

This study shows that small fish such as bullhead may use different microhabitats during the day than at night. However this response seems to affect only a fraction of all fish examined. Loach, both in the field and experimentally, showed a peak of activity at dusk which decreased during the hours of darkness. Little or no activity was recorded during daylight hours (Smyly, 1955; Welton et al., 1983). Bullhead avoid areas that are directly illuminated by daylight and are mainly active at night (Andreasson, 1969; Andreasson, 1973; Gaudin \& Caillere, 1990). Like loach, bullhead become active at dusk with the peak of activity just after sunset (Andreasson, 1969; Welton et al., 1983). Zweimuller (1995) in a field

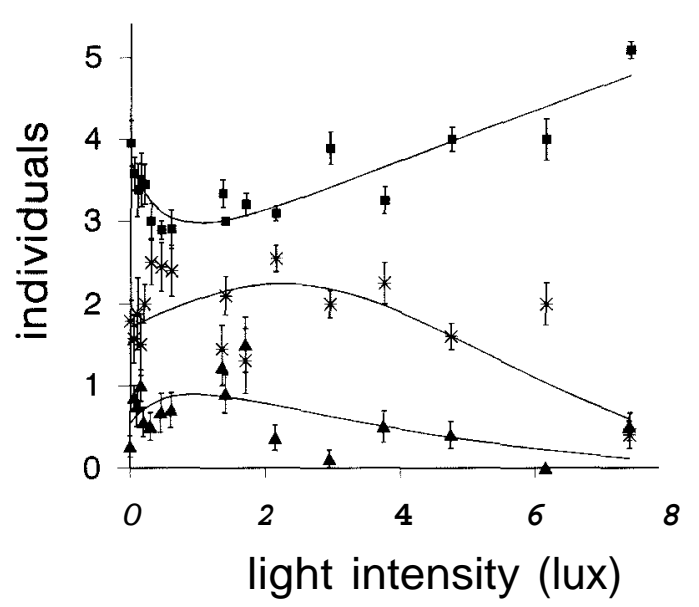

$$
\text { - deep * medium * shallow }
$$

Figure 3. Mean number of bullhead ( $\pm 1 \mathrm{SE}$ ) vs. light intensity at three depth levels. (deep:15 cm; medium: $10 \mathrm{~cm}$; shallow: $5 \mathrm{~cm}$ ). Numero medio de cavilats $( \pm I$ EE) frente a la intensidad de la luz a tres profundidudes distintas (profundo: $15 \mathrm{~cm} ;$ medio: $10 \mathrm{~cm}$; somero: $5 \mathrm{~cm}$ ). 

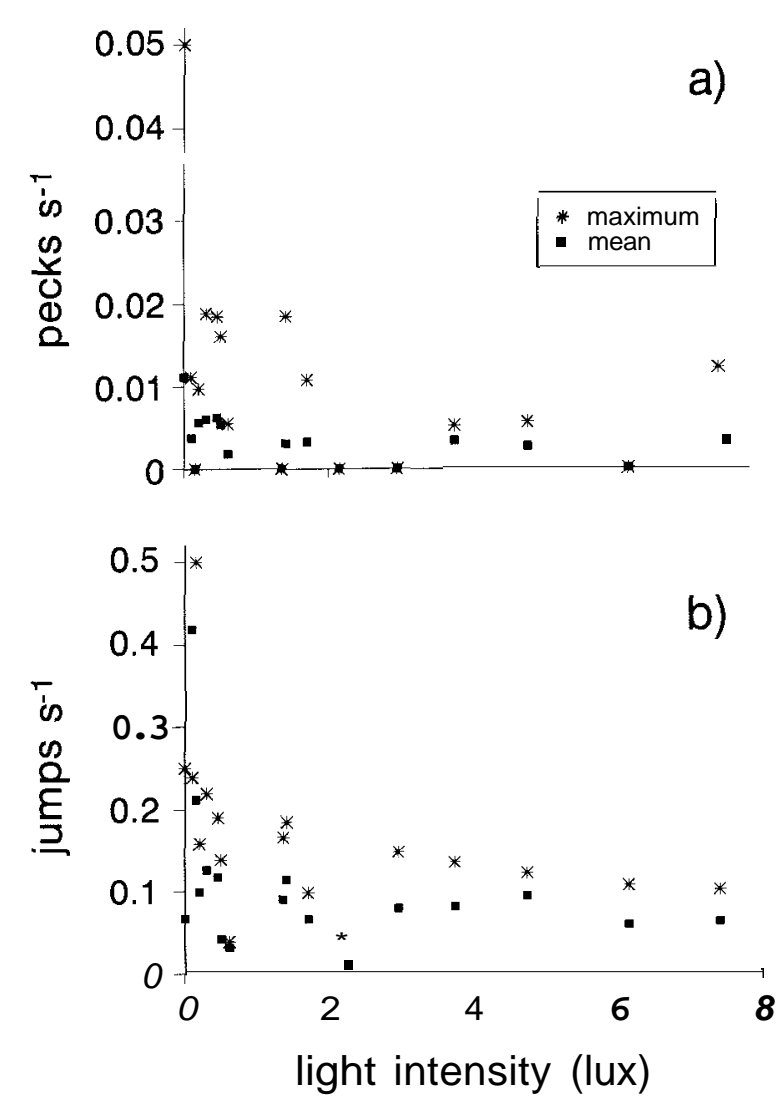

Figure 4. Relationship between maximum and mean bullhead activity (pecks s-1, jumps s-1) vs. light intensity. Relación entre la actividad máxima y media del cavilat (picoteos $s^{-1}$, salto $s^{-1}$ ) frente a la intensidad de la luz.

study of stone loach and gudgeon found a correlation between water depth at the fish resting places and the mean water depth. In this study (Zweimuller, 1995) a shift from rather protected resting places to more exposed resting places during periods of higher activity was observed.

In our experiments, fish prey (benthic chironomids) apparently were homogeneously distributed into the substratum as we did not observe any clumped distribution of these dipterans. Thus food dispersion did not seem to affect fish distribution between depth levels. In fact there were no differences in pecking activity between the three depth levels, which may be indicating that individuals were feeding similarly in each level. Most indivi- duals stayed in the deepest level, thus reducing their per capita potential food resources. This may have increased competition between those occupying the deep level, which in turn may have driven off a few individuals to the shallowest level. However, this only happened when light intensity was zero or near zero (i.e. at dusk or during night) and may be a response to predation risk.

Fish respond to predators by moving into protective habitats. In streams, shallow water areas have this function. Field and laboratory experiments of stream fishes have shown that small fish (Phoxinus phoxinus) select shallower areas when instream predators are present than when they are absent (Eklov et al., 1994). An alternative view is that fish use shallow habitats in response to higher food availability, rather than to the effect of predators. In the aquarium no predator was present but nevertheless bullhead and the other species displayed a tendency to move to the shallower level when light intensity decreased. By feeding at night in the shallow banks these individuals may use highly productive but otherwise risky habitats, which can be used during daylight by wading predators, like herons (Ardea sp.) (Britton \& Moser, 1982). On the other hand, Fraser \& Cerri (1982) observed that daylight reduces the influence of piscivorous fish because they are inactive at these times. These fish display nocturnal predator activity that may drive off prey from deeper locations. Thus, wading predators preclude the use of shallow areas by small fish during daylight and, at night, instream predators may force small fish from deep to shallow areas.

Table 2. Summary of linear regression between the light intensity (independent variable) and means and maximum values of bullheads activity (dependent variables). $n=17$. Resumen de la regresión lineal entre la intensidad de la luz (variable independiente) y los valores medios y máximos de la actividad del cavilat (variables dependientes). $n=17$.

\begin{tabular}{llccc} 
activity & & $\mathbf{F}$ & $\mathbf{P}$ & $\mathbf{R}^{\mathbf{2}}(\boldsymbol{\%})$ \\
\hline pecks s$^{-1}$ & Maximum & 4.5 & 0.05 & 23.2 \\
& Mean & 4.5 & 0.05 & 23.1 \\
jumps s$^{-1}$ & Maximum & 5.9 & 0.028 & 28.2 \\
& Mean & 3.6 & 0.076 & 19.6 \\
\hline
\end{tabular}


In the Mill stream, where the fish were captured, bullhead and the other species have evolved with large instream predators such as pike (Esox lucius) and trout (Salmo trutta) (Mann, 1971, 1980).At this site, bullhead did not coexist in the same habitat patches as large trout (Prenda et al., 1997). This may indicate that both predator and prey display in the field both complementary distribution and daily activity patterns.

Copp \& Jurajda (1993), studying a fish community in River Morava, concluded that the inshore areas such as shallow banks represent important night-time habitats for small-bodied and young riverine fishes, either as refuge from predation or for feeding on littoral organisms. With our experiment we have found the same behaviour in small fish, but the precise mechanism that produced it (predation risk or the use of richfeeding areas) needs to be further investigated.

\section{ACKNOWLEDGEMENTS}

We thank A. Grayston for lab assistance and S. Clough for his useful comments and suggestions to an earlier version of the manuscript. This research was supported by a Fleming Grant from the Spanish Ministry of Education and Science and The British Council to the first author.

\section{REFERENCES}

ANDREASSON, S. 1969. Locomotory activity patterns of Cottus poecilopus and Cottus gobio. Oikos, 20: 78-94.

ANDREASSON, S. 1973. Seasonal changes in diel activity of Cottus poecilopus and Cottus gobio (Pisces) at the Arctic Circle. Oikos, 24: 16-23.

BRITTON, R. H. \& M. E. MOSER. 1982. Size specific predation by herons and its effect on the sexratio of natural population of the mosquito fish Gambusia affinis Baird and Girard. Oecologia, 53: 146-151.

COPP, G. H. \& P. JURAJDA. 1993. Do small riverine fish move inshore at night? J. Fish Biol., 43: 229-241.
DIEHL, S. 1988. Foraging efficiency of three freshwater fishes: effects of structural complexity and light. Oikos, 53: 207-214.

EKLOV, A. G., L. A. GREENBERG \& H. KRISTIANSEN. 1994. The effect of depth on the interaction between perch (Perca fluviatilis) and minnow (Phoxinusphoxinus). Ecol. Freshwat. Fish, 3: $1-8$.

FRASER, D. F. \& R. D. CERRI. 1982. Experimental evaluation of predator-prey relationships in a patchy environment: consequences for habitat use patterns in minnows. Ecology, 63: 307-313.

GAUDIN, P. \& L. CAILLERE. 1990. Microdistribution of Cottus gobio L. and fry of Salmo trutta L. in a first order stream. Polsk. Arch. Hydrobiol., 37: 81-83.

MANN, R. H. K. 1971. The populations, growth and production of fish in four small streams in southern England. J. Anim. Ecol., 40: 155-190.

MANN, R. H. K. 1980. The numbers and production of pike (Esox lucius) in two Dorset rivers. J. Anim. Ecol., 49: 899-915.

POWER, M. E. 1984. Depth distributions of armored catfish: predator-induced resource avoidance? Ecology, 65: 523-528.

PRENDA, J., P. D. ARMITAGE \& A. GRAYSTON. 1997. Habitat use by the fish assemblages of two chalk streams. J. Fish Biol., 51: 64-79.

SCHLOSSER, I. J. 1988. Predation risk and habitat selection by two size classes of a stream cyprinid: experimental test of a hypothesis. Oikos, 52: 36-40.

SMYLY, W. J. P. 1955. On the biology of the stone loach Nemacheilus barbatula (L.). J. Anim. Ecol., 24: 167-186.

SMYLY, W. J. P. 1957. The life-history of the bullhead or Miller's thumb (Cottus gobio L.). Proc. Zool. Soc. Lond., 128: 431-453.

WELTON, J. S., C. A. MILLS \& E. L. RENDLE. 1983. Food and habitat partitioning in two small benthic fishes, Noemacheilus barbatulus (L.) and Cottus gobio L. Arch. Hydrobiol., 97: 434-454.

WELTON, J. S., C. A. MILLS \& J. R. PYGOTT. 1991. The effect of interaction between the stone loach Noemacheilus barbatulus (L.) and the bullhead Cottus gobio (L.) on prey and habitat selection. Hydrobiologia, 220: 1-7.

ZWIEMULLER, I. 1995. Microhabitat use by two small benthic stream fish in a 2 nd order stream. Hydrobiologia, 303: 125-137. 